\title{
Ecosystem service enhancement for the alleviation of wildlife- human conflicts in the Aravalli Hills, Rajasthan, India
}

Dr Mark Everard, University of the West of England (UWE), Coldharbour Lane, Frenchay Campus, Bristol BS16 1QY, UK (mark.everard@uwe.ac.uk, +44-(0)-7747120019).

Dr Dharmendra Khandal, Tiger Watch, Maa Farm, Sherpur Khiljipur, District Sawai Madhopur, Rajasthan, India 322001 (dharmkhandal@gmail.com,+91-9001507777).

Y K Sahu, Field Director, Ranthambhore Tiger Reserve, Sawai Madhopur, Rajasthan, India, 322001 (yksahu@yahoo.com,+91-9414043161).

\begin{abstract}
Conflict between people and ecosystem capacity is a global problem, and achievement of wildlife-human co-existence a strategic global need. Apex predators suffer disproportionately, including conflicts with human activities. Recovery of formerly declining predator populations, particularly India's Bengal tiger (Panthera tigris tigris), increases potential human conflict. Habitat conversion for arable production and proliferation of non-native tree species increases likelihood of conflict between wildlife, people and stock in villages in the Amlidha buffer zone between core areas of the Ranthambhore Tiger Reserve. Arresting and reversing landscape conversion in targeted zones can reduce potential wildlife-human conflict by regenerating ecosystem capacity, enabling coexistence of a 'green corridor' for terrestrial wildlife migration, a 'blue corridor' for movement of riverine wildlife, and sustainable human livelihoods. This can be achieved through informed and consensual community-based zoning of land uses, management of non-native species and regeneration of local water resources. Conversely, continuing habitat simplification will decrease ecosystem vitality and services, increasing wildlife-human conflict and insecurities. Transition to multifunctional ecosystem management doesn't require wholesale change; elective, consensual adjustments can enhance socio-ecological security. Initiatives by the NGO Tiger Watch involving village people, whose willing engagement is essential for sustainable management, support potential achievement simultaneous wildlife conservation and human benefits.
\end{abstract}

\section{Keywords}

Tiger; Ranthambhore; conflict; conservation; livelihoods; community

\section{Introduction}

Current human population and development trajectories are escalating potential conflicts with wildlife species, ecosystems and their many beneficial processes and services (Millennium Ecosystem Assessment, 2005a). Schipper et al. (2008) found that $25 \%$ of mammals worldwide are facing extinction, with carnivores the most threatened. Apex predators have experienced catastrophic declines throughout the 
world as a result of habitat loss and persecution, commonly also associated with dramatic increases in the abundance of smaller predators (Prugh et al., 2009). The tendency of large carnivores to roam exposes them to edge effects peripheral to constrained areas, such as wildlife reserves, potentially leading to human-carnivore conflicts including threats to livestock (Balme et al., 2009). Habitat conversion, particularly deforestation, exacerbates pressures on carnivores (Chávez and Ceballos, 2006).

Conservation of apex predators can be controversial, depending on attitudes towards large carnivores which vary widely between villages, regions and countries, ranging from perception of these animals as symbols of natural systems or a threat to human lives and livelihoods (Silva et al., 2013). In other localities, top predator species may have particular spiritual value (Wilson, 1990) contributing to taboos or other social protocols serving to promote their conservation. Conversely, they may also constitute lucrative targets for trade by poacher networks, generally illegally serving international markets (Abernethy et al., 2013). Illegal hunting of carnivores and their prey is one of the highest priority concerns for their conservation (Rosas and Valdez, 2010; Treves and Karanth, 2003).

The creation of nature reserves is one societal response to protection of areas important for wildlife, geological formations and, sometimes, culturally important landscapes. The world's first such reserve dates back to the $3^{\text {rd }}$ century BC in Sri Lanka (Department of Survey, 2007). A wide range of religious, sporting and nature conservation motives historically underlie the founding of reserved areas, which are often located in habitat too inhospitable for agricultural conversion and therefore historically left 'wild' for practical reasons. Also, the formation of nature reserves has not infrequently been associated with forced displacement of indigenous people as a form of 'environmental racism' (Merchant, 2007). A full review of the history of protected areas is beyond the scope of this paper. However, the global network of nature reserves today serves as a bulkhead of varying efficacy against human encroachment and habitat conversion for narrow ends, and as a genetic reservoir largely free of human interference beyond low-intervention tourism and, not uncommonly, traditional uses as a historic right by indigenous communities. Notwithstanding these important conservation successes, it is increasingly recognised that large animals, particularly those with migratory or territorial habits, may be restricted by reserve size. Also, under a changing climate, there is a need to enable the movement of species north-to-south and between altitudes in response to temperature regimes and east-to-west in response to changing rainfall patterns. Consequently, future development of protected areas needs to integrate landscapescale connections and processes, and to manage fragmented wildlife under the ecosystem approach if it is to remain viable and valuable to society (Lawton, 2010). This is particularly the case where large carnivores are concerned, territory size frequently leading to straying of animals beyond protected area boundaries and so necessitating effective management to enable humans and predatory species to coexist in the long term in buffer areas surrounding reserves (Silva et al., 2013).

Beyond the need for habitat to provide cover and other behavioural purposes, loss of habitat can lead to reductions in prey that may in turn create a major limiting factor for the survival of large predators (Carbone et al., 2011). Reduced habitat extent and quality in buffer zones can thereby discourage predator movement and, due to 
lack of semi-natural areas and their associated concealment and potential to provide wild food, may also promote risk of attack on stock animals and other more direct human conflicts.

To address some of these pressures, particularly in response to formerly catastrophically declining populations of India's iconic Bengal tiger (Panthera tigris tigris) through pressures such as habitat conversion and poaching, the Government of India launched Project Tiger in 1972 during Prime Minister Indira Gandhi's tenure. The purpose of Project Tiger was to counter the decline of the Bengal tiger, ensuring viable populations in their natural habitats and also to protect them from poaching and other threats of extinction. Project Tiger was one of a set of apex species-driven conservation initiatives undertaken with the assumption that benefits $s$ would ramify for the whole food chain and habitat quality, though monitoring has been primarily driven by reporting animal censuses with little attention to assessment of habitat quality and linked biodiversity and ecosystem service values. The tiger Panthera tigris, and its multiple sub-species, is listed as 'Endangered: Population Decreasing' on the IUCN Red List of Threatened Species (IUCN, 2017: http://www.iucnredlist.org/details/15955/0). Project Tiger envisioned networks of Tiger Reserves across India, funded to protect and restore habitat, as breeding nuclei from which excess animals could migrate to adjacent forests (Panwar, 1987). The Indian government also set up a Tiger Protection Force to combat poachers and to fund relocation of villagers to minimise human-tiger conflicts. Establishing formal protection areas is important for tiger conservation, as is the effectiveness of protection in these designated areas (Chape et al., 2005). However, species with large home ranges or migratory habits present broader challenges, because their habitat requirements often extend beyond the boundaries of protected areas (Lambeck, 1997; Caro and O'Doherty, 1999; Sanderson et al., 2001). Principal threats to tigers both within and beyond protected areas include direct hunting but also declines in their prey, exacerbated by habitat loss associated with agricultural, urban and infrastructure expansion, and extractive resource consumption such as logging and mining (Linkie et al., 2003; O’Brien et al., 2003; Dinerstein et al., 2007).

Today, a combination of pressures is increasing the potential for human-wildlife conflict:

- Increasing tiger numbers. Recent anti-poaching and wider conservation measures have seen a welcome reversal in the former decline of tiger numbers in India. Estimates, on the basis of camera traps, record an increase from some 1,411 individual Indian tigers in 2006 (Jhala et al., 2008) to 2,226 individuals in a census report released in January 2015 (Jhala et al., 2015). As anticipated, territorial behaviour is leading to tigers straying beyond the porous boundaries of Tiger Reserves, not only into and across buffer zones and surrounding peripheral zones but also beyond them.

- Increasing human numbers. India's human population continues to grow, rising from 361 million in 1951 to 683 million in 1981 and 1.21 billion in 2011

(Government of India, 2011) and reaching an estimated 1.25 billion in July 2015 representing one-sixth of the global population (CIA, 2015). This broad trend is mirrored in the Indian state of Rajasthan, with a 2001 population of 56.5 million rising to 68.6 million by 2011 (Government of India, 2011). 
- Increasing water stress and associated vulnerability to drought. This is largely related to abandonment of centuries-old localised, community-based capture of monsoon rains in favour of mechanised exploitation of available resources. Abandonment of traditional water resource recharge practices is being substantially driven by a policy environment strongly favouring individual energised pumping of receding groundwater (reviewed by Everard, 2015), as well as the damming and diversion of water to serve major population centres depriving rural catchments of natural flows (Srinivasan et al., 2009). There is a distinct lack of balancing measures to maintain or promote groundwater recharge. This pressure on water resources is also substantially amplified by the demands of a growing human population and an increasingly unstable climate. Reduced water availability across landscapes, particularly in proximity to human settlements, can only increase the potential for conflict in and around remaining resources.

Singh et al. (2015a) characterised and examined the causes of human-tiger conflicts in pastoral villages adjacent to Ranthambhore Tiger Reserve in semi-arid north-eastern Rajasthan, India, throughout 2005-2011. 113 conflicts were recorded of which $88.5 \%$ were attacks on domestic livestock and $11.5 \%(13)$ attacks on humans, with of combined attacks $53.4 \%$ occurring inside villages, $44.5 \%$ in agriculture fields and $1.9 \%$ in forests $(1.9 \%)$. Noting that the highest conflicts occurred in the summer and during the monsoon, Singh et al. (2015a) attributed human-tiger conflicts to tiger movements, fragmentation of corridors and human disturbance. Though literature is lacking about trends in conflict around Ranthambhore over time, evidence of current issues and increasing tiger numbers, human populations and habitat conversion suggests that human-tiger conflicts are likely only to increase on current development trajectories, necessitating novel conservation and management approaches. This paper tests whether, and how, conservation and restoration of ecosystem services can contribute to alleviating wildlife-human conflicts in a wildlife corridor through a buffer zone between two protected wildlife Reserve areas comprising key elements of the Ranthambhore Tiger Reserve.

\section{Methods}

This section describes relevant characteristics of the study site (Ranthambhore National Park, the Keladevi Wildlife Sanctuary, the Banas River and Amlidha Village). It also addresses methods used to observe and gather information about the status and trends of these locations.

\subsection{Ranthambhore Tiger Reserve}

Ranthambhore Tiger Reserve is situated in south-east Rajasthan, a part of the Aravalli mountain range, extending between latitude $25^{\circ} 54^{\prime} \mathrm{N}$ to $26^{\circ} 12^{\prime} \mathrm{N}$ and longitude $76^{\circ} 23^{\prime} \mathrm{E}$ to $76^{\circ} 39^{\prime} \mathrm{E}$. The Reserve covers a total area of $1,394.64 \mathrm{~km}^{2}$, spanning Ranthambhore National Park $\left(392.5 \mathrm{~km}^{2}\right)$, Keladevi Wildlife Sanctuary (674 $\mathrm{km}^{2}$ ), Sawai Mansingh Wildlife Sanctuary $\left(127.6 \mathrm{~km}^{2}\right)$, Qualji Closed Area $\left(7.58 \mathrm{~km}^{2}\right)$ 
and other forest areas (132.96 km²) (Thorat and Gurjer, 2010; Jhala et al., 2011; Singh et al., 2015b). (Figure 1.)

Ranthambhore National Park was amongst the first nine Tiger Reserves declared in 1973 at the launch of Project Tiger in India, then encompassing the former Sawai Madhopur Wildlife Sanctuary, Sawai Mansingh Sanctuary, Kualji Close and some other forest areas. It has since expanded. Aside from its extraordinary wildlife diversity, Ranthambhore National Park also encompasses substantial and significant archaeological richness notably including the 1,000 year old Ranthambhore fort and numerous temples, cenotaphs, tombs, stepped wells and summer palaces from India's medieval period. The park is also of significant tourism value, drawing in visitors from around the globe as it is recognised as the best Tiger Reserve in India and indeed the world.

Keladevi Wildlife Sanctuary is the northern extension of the Ranthambhore Tiger Reserve in Karauli and Sawai Madhopur districts. It spans $674 \mathrm{~km}^{2}$ encompassing two separate ridges of hills running parallel to each other in its southern, northern and eastern parts. Like Ranthambhore National Park, its dry hills are densely forested with native dryland tree species, particularly Dhonk (Anogeissus pendula).

The study area is confined to the corridor between Ranthambhore National Park and Keladevi Wildlife Sanctuary. This land predominantly comprises Revenue Land (designated as agricultural land on which construction of buildings is not permitted). The corridor is approximately $150 \mathrm{~km}^{2}$ in total area, and approximately $14 \mathrm{~km}$ long extending in a south-westerly direction. The gap between the two protected areas ranges between 2.6 to 8 kilometres. The majority of this corridor primarily comprises the Banas River and its adjacent sand banks, with some peripheral forest cover. The presence of the dry bed of the Banas River as flow recedes following the monsoon, seasonal tributary rivers, shallow marginal waters and complex ravine structures provide diverse habitat for wildlife (Forest Department, 1990).

\subsection{Amlidha area}

Amlidha area (also Amli Dha) is situated in the buffer zone between Ranthambhore National Park and the closely adjacent Keladevi Wildlife Sanctuary, which are separated by the corridor of the Banas River (Figure 1). Several villages exist in this area, including Kala Khora, Gadhin and Talra Khet, cumulatively encompassing eighty (80) households. Livelihoods in the village are predominantly agricultural, with growing arable production and extensive herding of goats as well as some buffaloes.

Figure 1: Ranthambhore Tiger Reserve, comprising (RNP), Keladevi Wildlife Sanctuary (KWLS), Sawai Mansingh Sanctuary (SMS) and the Bundi Buffer zone. RNP and KWLS are separated by the Banas River. 


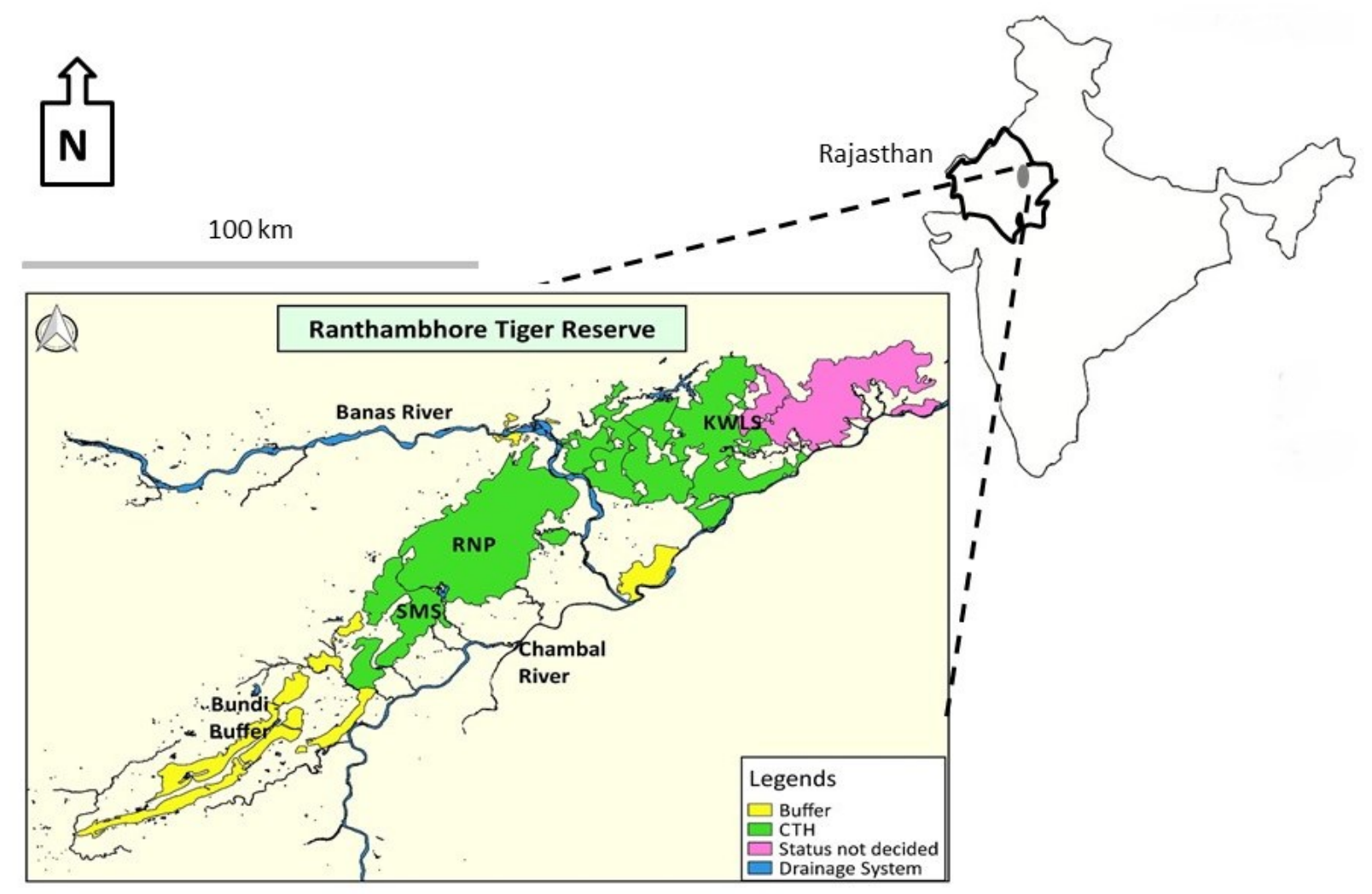

\subsection{The Banas River}

The Banas River runs in a valley between the Keladevi Wildlife Reserve to the north and Ranthambhore National Park to the south, before joining the Chambal River that is itself a tributary of the Yamuna, which in turn joins the Ganges. The Banas River originates in the Khamnor hills of the Aravali range, its $512 \mathrm{~km}$ length and catchment area of $45,833 \mathrm{~km}^{2}$ entirely within Rajasthan (Department of Water Resources, 2000; Upadhyay and Rai, 2013). The river is also known as the Van Ki Asha, or 'Hope of forest'. Flowing from the drier lands to the west of Ranthambhore, the Banas has a pronounced seasonal flow regime responding to monsoon rainfall.

The Bisalpur Dam was built on the Banas River to impound its water in the Bisalpur Reservoir some $150 \mathrm{~km}$ upstream of the river's confluence with the Chambal.

Bisalpur Reservoir has a total capacity of 1.1 billion $\mathrm{m}^{3}$ water and a surface area of $218.36 \mathrm{~km}^{2}$, developed to provide drinking water for the city of Jaipur some $140 \mathrm{~km}$ to the north (Central Water Commission, undated). The Bisalpur-Jaipur project was completed by the Government of Rajasthan in 2009 (The Hindu, 2013). The substantial quantities of water abstracted from Bisalpur Reservoir, and also evaporated from its open surface under intense desert edge conditions, is lost to the Banas system. Water levels in the Banas are further compounded today by largely illegal extensive sand and gravel mining destroying the structure of the exposed river bed, further suppressing the groundwater table (Times of India, 2013). These water losses starve the river of dry weather flows outside of the monsoon season, affecting the catchment including its corridor in the buffer zone between Ranthambhore National Park and the Keladevi Wildlife Sanctuary. 
People in the villages of Amlidha mostly obtain water for domestic use from pumped tube wells close to villages, with some pumped from the Banas River and transported in small quantities by women, or in larger quantities by vehicles. The flows of the Banas dwindle significantly in the summer. Water stress is commonplace in Amlidha, though mechanised extraction has resulted in substantial cessation of traditional rainwater harvesting practices. Some representative quotes from villagers include: "We obtain our water from pumps; we do not need to harvest and store monsoon rainfall underground", "The river now gets very low in the summer; I worry that it may dry up completely" and "If our animals needs water we take them to the river". These highlight abandonment of local groundwater recharge practices, with a high dependency on a degree of mechanised assistance in surface water resources that are recognised as diminishing.

\subsection{Assessment of wildlife, habitat and societal status and trends}

Wildlife passage and trends in habitat change and human activities were collated from a variety of sources, including: camera traps; unpublished Tiger Watch surveys; semi-structured interviews with local herders; semi-structured interviews with people in villages of Amlidha; and direct observations of habitat, landscape use by people and wildlife between January and April 2016 (the pre-monsoon season). Online maps were also analysed, including using the 'measure distance' function of Google Maps (https://www.google.co.uk/maps).

A total of 40 Cuddeback Attack 2 camera traps were set at night and maintained in strategic locations (often near paths) around Amlidha by a network of seven (7) 'goatwala for tigerwala' volunteers recruited by Tiger Watch from the traditionally herding Gujjars tribal community from villages in Amlidha (Bengali, 2016). In addition to serving this monitoring purpose, 'goatwala for tigerwala' volunteers also serve as community activists for tiger and other wildlife conservation (tigerwalas). They are paid for these services, though remain working largely as goat-herders (goatwalas) thereby embedding the benefits and education about conservation into the local community. Wildlife monitoring using camera traps is one of three strands of the Tiger Watch 'Village wildlife volunteers' programme, also including addressing wildlife-related crime (in collaboration with the Forestry Department) and responding to wildlife-human conflict (including placating locals and routing compensation payments to people losing stock to predation by tigers). Between January and April 2016, images of larger mammals from 200 trapping events were observed and species moving through the region were recorded (Eveleigh, 2016).

Unpublished Tiger Watch surveys covered a variety of taxa, including presence of reptiles and other organisms in the seasonally inundated floodplain of the Banas River.

Semi-structured interviews with 'goatwala for tigerwala' volunteers as well as a further 40 goat-herders recorded information about wildlife activity, conflicts with livestock stock and people, and changes in land use including arable conversion. Semi-structured interviews were also undertaken with 40 non-herding occupants in villages of Amlidha, including arable farmers and other people encountered during visits. Quotes were recorded from all those interviewed, but these were anonymised 
so that people felt free to express opinions without fear of reprisals for unpopular views.

Direct observations of habitat, landscape use and wildlife from January to April 2016 spanned 8 visits by Tiger Watch (Khandal), and a longer site visit in April 2016 during the dry summer period by the two senior authors particularly visiting remnant pools and residual flows of the Banas River. Features observed during these visits were recorded, though as notes rather than in a formally structured manner. These observations were substantially supported by extensive experience and data held by the NGO Tiger Watch (much of it unpublished).

\section{Results}

This Results section addresses selected features of the status and trends in wildlife, habitat and social factors based on the methods above. Anonymised quotes are reproduced where relevant.

\subsection{Habitat characteristics and change}

Electronic mapping tools determined that the Banas River corridor between breaks of slope through the Amlidha buffer zone varied in width, but was most constricted at one point to approximately $2.6 \mathrm{~km}$ where the steeper rocky hills of Ranthambhore National Park and the Keladevi Wildlife Reserve were closest together.

River habitat was observed to be complex. Much of the floodplain, seasonally inundated after monsoon rains, comprises extensive tracts of sand with only sparse woody vegetation. Tiger Water surveys (unpublished) have revealed substantial populations and diversity of desert reptiles (including for example Red-headed Royal Snake (Spalerosophis atriceps), fringed-toed lizard (Acanthodactylus cantoris) and Desert Monitor Lizard (Varanus griseus)) in this sandy floodplain zone, reflecting connectivity with the up-catchment desert regions through which the Banas flows. However, for approximately two months of an average year, this substantial 'desert' area comprises the bed of the Banas River as it fills its extensive floodplain following monsoon rains. The temporal complexity of this desert/riverbed habitat is further increased by human uses for flood-retreating crops, for which residual parallel ridge and furrow channels were observed during the dry April 2016 site visit, as well as foraging by goat herds (Figure 2). These uses appear to be largely sympathetic with the seasonally highly variable natural character of the wetland, consistent with 'wise use' principles as defined by the Ramsar Convention Secretariat (2010).

Figure 2: Ridge and furrow remnants of flood retreating cultivation in the sandy floodplain of the Banas River abutting cliffs on the border of Ranthambhore Tiger Reserve (image (C) Mark Everard). Low resolution image only inserted here to aid reviewers 


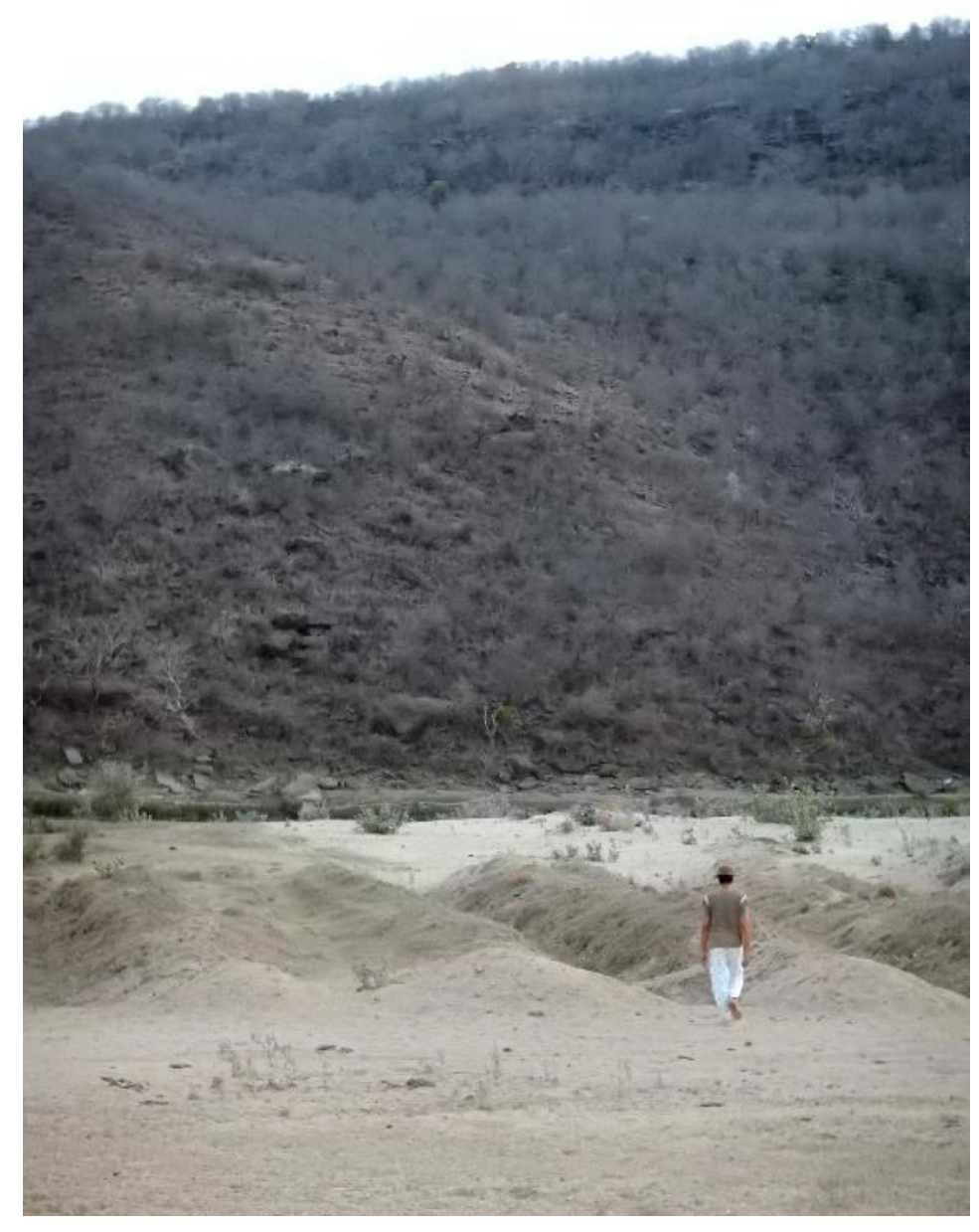

Less sympathetic with ecosystem character and integrity was the widespread flattening of ravines for conversion to arable land, observed as an increasing trend over recent years in many parts of the outer edges of the river corridor in the study site (Khandal and Khandal, 2013). Villagers reported that "We fill in the ravines to make bigger fields on which to grow food". When asked about implications for wildlife movement, a comment representative of common views was "We drive off grazing animals that eat our crops during the day, though it is dangerous to be out in the fields at night due to tigers and leopard". The prevalence of herbivores and carnivores was thus widely acknowledge ("All of us see tigers and leopard very often") though human-large carnivore conflicts were rare.

Whilst supporting farmed food production, this form of habitat simplification was observed to severely degrade the heterogeneous habitat provided by steep ravine topography and its associated native scrub vegetation. It thereby substantially reduces the value of riparian habitat for a variety of wildlife, including predators, prey, plants and many other taxa. Simplification of ecosystems and their service production by conversion for increasingly intensive arable farming in zones critical as wildlife corridors may potentially reduce cover, habitat suitable for other uses by wildlife as well as substantial reductions in natural prey populations that may then enhance the risk of wildlife-stock and potentially more direct wildlife-human conflicts. Worryingly, the Madhya Pradesh state government is promoting the flattening of ravines on the banks of the nearby Chambal River, which forms a border with Rajasthan, in a narrowly economically framed aspiration to create 1.8 million ha of 
cultivable plots to promote agriculture and jobs regardless of implications for the important Chambal ecosystem (Hindustan Times, 2015). Farias and Jaksic (2011) observe similar impacts on biodiversity and functional richness, with top predators and their ecosystem functioning impacts proving particularly vulnerable to changes in land use and habitat fragmentation in a Chilean forest.

Direct observations and discussions with herders as well as tigerwalas showed that the whole river corridor was also used opportunistically for rough grazing, predominantly by goats and water buffalo. This practice was observed to retain overall habitat structure and hence associated functioning and production of ecosystem services. As observed in the representative quote above, the community has adapted practices to avert risks of livestock encounters with large predators. There are nevertheless some losses to tiger and leopard predation, for which Tiger Watch placates locals and routes compensation payments through its locally embedded network to people losing stock. This assistance was seemingly effective, as evidenced by no negative stated attitudes to large carnivores from those interviewed in Amlidha.

Figure 3: Complex ravine habitat structure bordering an unconverted reach of the Banas River (image (c) Mark Everard). Low resolution image only inserted here to aid reviewers

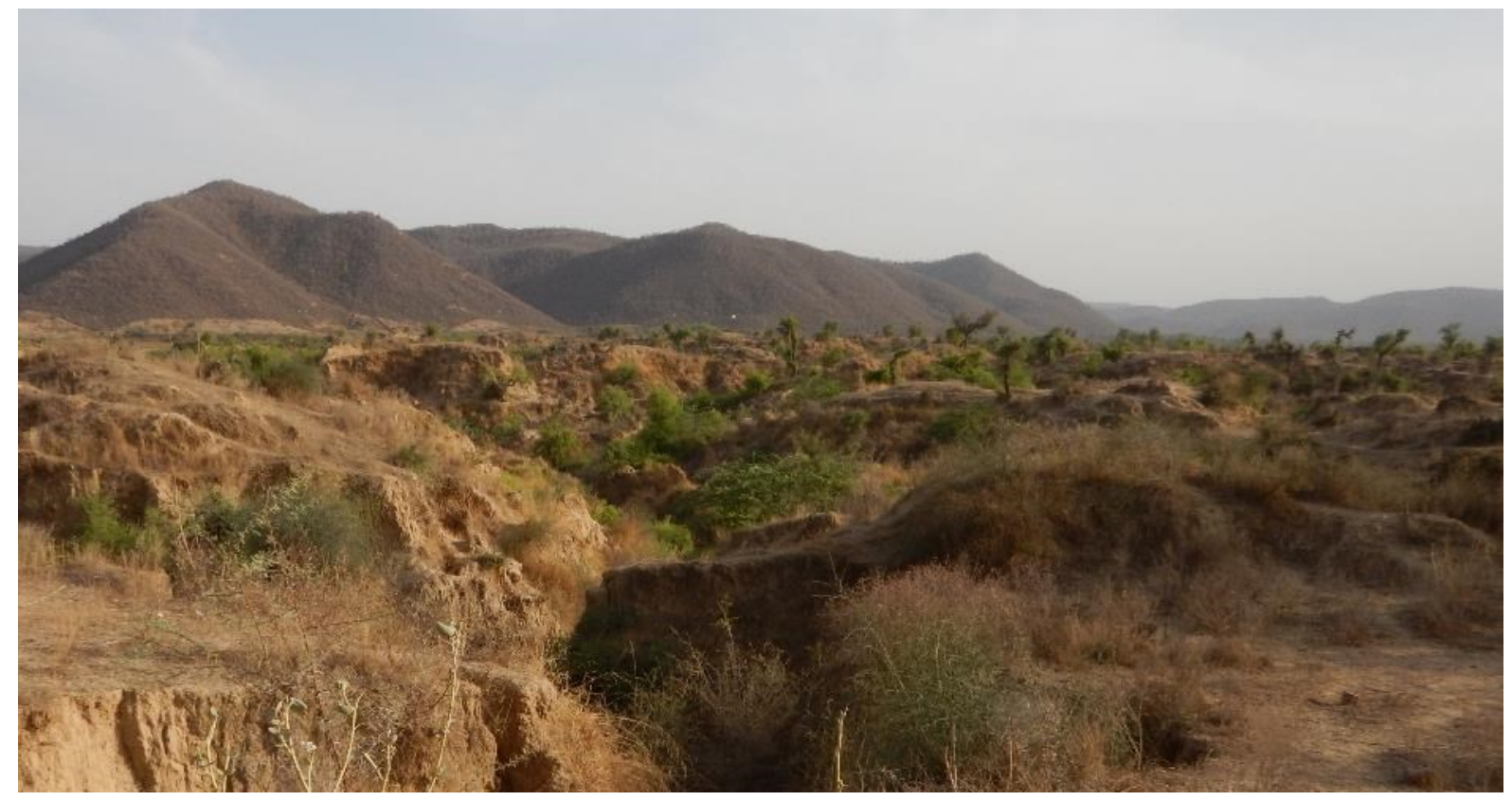

Changes in vegetation directly or indirectly due to human activities also create pressures on ecosystem integrity, ecosystem services and utility for both people and wildlife. Dikhni babul (Prosopis juliflora), also known as ganda babul ('wild babul' in Hindi) and in its native South America as mesquite, is a thorny tree of the family Fabaceae and sub-family Mimosoideae. The tree is native to Mexico, Central and northern South America, though now naturalised and frequently invasive in the Indian Sub-continent as well as in parts of Australia, Brazil (beyond its native range), Africa, western Asia, Arabia and Hawaii (BioNET-EAFRINET, undated). P. juliflora was first introduced to India in 1877 , since becoming invasive and widely exploited 
as a source of fuel wood, fodder and charcoal (Kaur et al., 2012). Wood remains the primary cooking fuel for some $70 \%$ of India's rural population in dry environments, into which Prosopis juliflora has been introduced and widely naturalised due to its faster growth than native trees, now providing some $75 \%$ of fuel wood needs in arid and semi-arid parts of north-west, central, west and south India (Tewari et al., 2000).

In Amlidha and much of this region of Rajasthan, the tree is not only strongly established with many spontaneous strands but has been actively planted in many places. Dikhni babul was observed commonly - indeed almost pervasively growing on road and path edges, field boundaries and disturbed ground across the study site. Many other trees of more local provenance have been removed to create large fields, and with them the loss of direct habitat for wildlife as well as associated ecosystem services such as shade and microclimate, water recycling and pollination.

In addition to other domestic uses, the strong, thorny branches of dikhni babul are used for a variety of purposes, including as fencing to protect stock (predominantly goats and buffalo) brought in at night and also for timber. However, a downside of the otherwise useful robust thorns is that dropped dikhni babul twigs stick into the pads of the feet of tigers, leading the animals to need to stop periodically to remove them with their teeth or to avoid farmed areas and potentially use paths closer to human settlements. Many villagers reported large predators and other wildlife preferentially using thorn-free paths through villages - a representative quote included "Tigers and leopard often pass through the village at night" and "We sometime see tigers stopping to pull thorns from their feet; they do not like to walk near [dikhni] babul trees" - observations that are correlated by the frequent capture of predatory animals and other mammals on camera traps (see below).

Displacement of native trees and vegetation appears to have further adverse consequences for ecosystem vitality and services. In a study of a spontaneously generated population in arid lands in Brazil, Riegelhaupt et al. (2008) found that Prosopis juliflora stands contributed to a considerable water deficit where potential evapotranspiration of around $1,600 \mathrm{~mm}$ year $^{-1}$ exceeded soil moisture recharge from $662.2 \mathrm{~mm}$ annual rainfall of which $550.3 \mathrm{~mm}(83.1 \%)$ is concentrated between February and July. Rainfall in Tonk District of Rajasthan is similar to that recorded in the Brazil study area, at an average of $668.3 \mathrm{~mm}$ year $^{-1}$ (Central Ground Water Board, undated), though virtually all of this falls in a more concentrated and increasingly erratic monsoon period between July and September. Alien, invasive tree species may therefore well increase water stress where they displace native trees and other vegetation better adapted to local semi-arid climatic conditions. In addition to the widespread abandonment of traditional groundwater recharge practices in preference to mechanised pumping from wells, water stresses across the landscape exacerbate competition and potential for conflict around accessible water. There are also reports that dikhni babul trees suppress growth of other vegetation under their canopies (Om Parkash Sharma, Wells for India, pers. comm.; Binggeli, 2001; Pasiecznik et al., 2001). Kaur et al. (2012) found that soil from the rhizosphere of $P$. juliflora had higher extractable phosphorus, soluble salts and total phenolics than the Indian native species Prosopis cineraria, and caused far greater mortality of native Indian species, suggesting that this was due to a potential allelopathic mechanism. The impacts of dikhni babul on native wildlife may therefore 
be driven by direct (displacement and planting for domestic use) as well as multiple indirect factors.

Recognition of increasing disbenefits can reverse local people's initial positive perception of Prosopis juliflora as a source of fuelwood and other beneficial uses (Binggeli, 2001). However, the pervasion of the plant in Amlidha suggests that the beneficial uses that people find for the tree currently outweigh any desire to replace it with native species lacking these negative impacts.

\subsection{Wildlife use of the river corridor}

A wide diversity of plant and animal species was observed during the 2016 site visits in and beside remaining pools in the Banas River and across its floodplain to the breaks of slope, albeit that these were not surveyed in a structured manner. Author observations were broadly consistent with reports from villagers and tigerwalas.

Use of the 'green corridor' across the buffer zone connecting Ranthambhore National Park and the Keladevi Wildlife Sanctuary by larger mammals was assessed in a more systematic manner by camera traps. Species of large mammals detected migrating through the Amlidha study site by the 40 'goatwala for tigertwala' volunteer-maintained camera traps are listed in Table 1.

Table 1: Species recorded moving through Amlidha by Tiger Watch (unpublished) using night-time camera traps

\section{Species recorded by Tiger Watch (unpublished) on camera traps}

- Tiger (Panthera tigris tigris)

- Ten different individual tigers were captured in camera traps by the Tiger Watch team in this area in a six-month period between December 2015 and May 2016.

- Leopard (Panthera pardus)

- Indian crested porcupine (Hystrix indica)

- Nilgai, or blue bull (Boselaphus tragocamelus)

- Cheetal, or spotted deer (Axis axis)

- Caracal (Caracal caracal)

- Jungle cats (Felis chaus)

- Striped hyena (Hyaena hyaena)

- Sloth bear (Melursus ursinus)

- Rusty spotted cat (Prionailurus rubiginousus)

- Indian Wolf (Canis lupus)

There is evidently extensive traffic of animals using the buffer zone 'green corridor' by night. This emphasises the importance of maintaining sufficient quantity and diversity of ecosystem services to enable people and wildlife to co-exist with minimal conflict, as well as effective resolution when conflict does occur. 
However, in addition to the 'green corridor' served by transit of the Banas River across the buffer zone, the Banas River itself also represents an important 'blue corridor' for the movement of river-related wildlife as well as the desert animals inhabiting the exposed sandbanks during the long drier months. Riverine organisms include a range of species from the truly aquatic to the amphibious right through to those that are tolerant of inundation and, as observed, a range of desert species.

In terms of fully aquatic species, large fish were observed. Some large species of the Chambal system, among them red-finned and golden mahseer (Tor tor and Tor putitora), are known to migrate upstream during monsoons to spawn in upper river reaches. Mugger crocodiles (Crocodylus palustris) inhabit residual pools in the Banas River during summer, and move along the river under higher flows, whilst the rare gharial (Gavialis gangeticus) has been reported as accessing the Banas River from its remaining stronghold in the Chambal River close to the confluence of the Banas. Terrapins (species not determined) were commonly observed during the site visit in the remaining summer pools of the Banas. A diversity of emergent and submerged wetland vegetation was also observed in remaining river channels and pools during the April 2016 site visit, including obligate hydrophytes such as Potamogeton crispus.

For wildlife as diverse as fully aquatic, wetland and desert-adapted plant and animal species, the 'blue corridor' provided by the Banas River is clearly of high conservation importance and equally vulnerable to disruption by unsympathetic human exploitation.

\subsection{Societal characteristics and change}

Interviews with selected local people, long-term liaison with Tiger Watch staff and direct observations during the April 2016 site visit endorsed many of the observed wildlife and land use and conversion trends noted above. An informal fisherman was also observed fishing illegally, and then fleeing on sight of our site visit team, in one of the remaining summer pools of the river where fishing is banned as it is part of the Tiger Reserve buffer zone. The fisherman abandoned fishing lures for capture of larger, predatory fish species as well as a gill net in which three fish species were observed to have been indiscriminately captured and killed: the Indian glassfish (Parambassis ranga) which does not exceed $8 \mathrm{~cm}$ in length (Fishbase, undated a); an unidentified cyprinid species with mouthparts suggesting an algal scraping diet; and the predatory catfish batchwa vacha (Eutropiichthys vacha) which grow to $34 \mathrm{~cm}$ and $1.4 \mathrm{~kg}$ (Fishbase, undated b).

People were also observed using the remaining waters of the Banas River for a variety of purposes. These included collecting water for household use, washing of clothes and vehicles, and bathing in shallow runs (stranded mugger crocodiles are one of the hazards of deeper pools), as well as direct abstraction of water using diesel pumps from the already critically depleted river.

\section{Discussion}


When populations of large predators and other large animals rebound, greater movement between and beyond constrained nature reserve areas is inevitable. Reversal of the long-term decline in tiger numbers in India and their spread into populated rural areas of India can result in conflicts where there is competition for ecosystem capacity. Buffer zones and wildlife corridor areas that are also human settlements therefore need to provide a sufficient diversity and quantity of ecosystem services for human and wildlife needs to be accommodated simultaneously.

Evidence of increasing ravine flattening for arable food production in the Amlidha buffer zone is a form of habitat simplification that boosts productivity of a narrow band of provisioning ecosystem services, but is likely to contribute to a commensurate rise in potential for conflict with wildlife within and passing through the area. Enhancement of food production for subsistence and income generation is legitimate, though landscape change responding to this narrow provisioning driver has occurred without significantly taking account of the wider breadth of interconnected ecosystem services formerly produced by semi-natural landscapes. One of the net outcomes of myopic, utilitarian conversion for desirable provisioning services has been loss of the natural heterogeneity of the Banas River floodplain and associated ravine habitat, with its associated diversity of ecosystem services. Left unconstrained, conversion of multifunctional habitat for narrowly framed agricultural benefits is likely only to replicate global trends wherein habitat conversion for farming constitutes a major pressure decreasing ecosystem vitality and service provision, constituting a longer-term source of hardship rather than human security (Millennium Ecosystem Assessment, 2005a and 2005b).

Increasingly mechanised extraction of water from the river and groundwater, locally but particularly upstream in the Bisalpur Dam, is taking place without balancing water extraction with recharge practices including the widespread abandonment of traditional monsoon run-off water harvesting measures to recharge groundwater resources insulated from the high evaporative losses. The starved flows of the Banas River, upon which the local community increasingly depends through increasingly mechanised extraction, compounds pressures in the river corridor created by direct habitat conversion. Elsewhere in Rajasthan and across India, restoration of community-based water harvesting, part of India's long and diverse tradition of water management for subsistence in arid conditions subject to only episodic rainfall, has proven a powerful stimulus for regenerating linked ecological and socio-economic wellbeing, with exemplar regions reversing cycles of decline and village abandonment (Jal Bhagirathi Foundation and Wells for India, 2010; Mahnot et al., 2012; Everard, 2015 and 2016; Davies et al., 2016; Wells for India, 2016). There are opportunities in the study site to invest in well-established rainwater harvesting techniques to alleviate pressures on water resources critical for people and wildlife and particularly given evidence of dwindling flows in the Banas river upon which there is increasing rural community dependency (Upadhyay and Rai, 2013), contributing to solutions to increase ecosystem service capacity in Amlidha for the simultaneous benefit of people and wildlife. Furthermore, the implications of displacement of native, dry-adapted vegetation by invasive, water-hungry species warrant further research. Where demonstrable benefit can be identified, a programme of eradication of alien, invasive tree species and their replacement with native, dry-adapted strains may be of significant benefit to landscape hydrology and thereby to the security of local people. This ecosystem-based approach through 
management of invasive vegetation to safeguard or regenerate water resources and associated ecosystem health and services has proven successful in dryland zones under South Africa's exemplar Working for Water programme, co-beneficially increasing income and employment opportunities amongst poor communities (Department of Environmental Affairs, undated). Removal of thorny alien trees that also contribute to potential conflicts, such as diverting wildlife through villages where they are more likely to encounter stock and people after darkness, could also make a significant contribution to peaceful co-existence of wildlife and the human community.

The concept of developing a 'blue-green corridor' optimally accommodating three sets of needs simultaneously - the 'green corridor' allowing free movement of wildlife between Reserve core zones crossing the river corridor, the 'blue corridor' enhancing porosity of riverine and desert wildlife along the river corridor, and the livelihood needs of the local people of Amlidha - is attractive and achievable. At its core is recognition of the interdependence of needs and community-level responses to address the importance of protection or regeneration of ecosystem capacity. This needs to occur on an appropriately spatially and temporally zoned basis, such that a sufficient quantity and diversity of permeable wildlife corridors and associated ecosystem services are available across the landscape simultaneously to enable wildlife movement and the needs of people with a minimum of conflict.

A growing literature links nature conservation with ecosystem service production. The association between biodiversity decline, ecosystem degradation and impacts on human wellbeing through the loss of beneficial ecosystem services is well established (Millennium Ecosystem Assessment, 2005; Díaz et al., 2006). There is therefore growing interest in exploring synergies between the goals of securing ecosystem services and conserving biodiversity (Turner et al., 2007; Naidoo et al., 2008; Mace et al., 2012). For tigers in particular, despite substantial reductions in habitat and population over the previous century, wild tigers still occur in 13 Asian countries, where their habitat overlaps with areas of high ecosystem service value, particularly for carbon storage and water filtration as well as areas of high plant diversity, important bird areas and the ranges of other threatened species (Kier et al., 2005). A 2015 report by the Indian Institute of Forest Management (Verma et al., 2015) found that Tiger Reserves also provide a range of associated economic, social, cultural and spiritual benefits, quantitative and qualitative estimates for up to 25 ecosystem services indicating a flow benefits emanating from selected Tiger Reserves ranging from Indian ₹8.3-17.6 billion $\mathrm{yr}^{-1}$ (£83-176 million $\mathrm{yr}^{-1}$ or \$US123261 million $\left.\mathrm{yr}^{-1}\right)$, translating into Indian ₹50,000-190,000 $\mathrm{ha}^{-1} \mathrm{yr}^{-1}\left(£ 500-1908 \mathrm{yr}^{-1}\right.$ or $\$ U S 742-2819 \mathrm{yr}^{-1}$ ), albeit that a large proportion of flow benefits are intangible and hence often unaccounted for in markets.

The above studies linking nature conservation with ecosystem service production all relate to areas that are either designated for protection of wildlife with clearance of people, or else were undertaken in remote locations. Therefore, the observed generation of multiple ecosystem services is likely to be as much a feature of unconverted landscapes as the presence of 'flagship' species, such as tigers. The situation in villages in the Amlidha buffer zone is that they are located between core areas of the Ranthambhore Tiger Reserve, where the livelihood needs of the population also has to be accommodated by the landscape. At present, evidence 
suggests that short-term livelihood needs predominate in decision-making leading to ravine flattening, with no planning of land use to take account of other needs including those that may generate conflicts, simultaneously fulfilling the needs of tigers, leopard and other large carnivores and animals whilst easing actual and perceived conflict with the interests of local communities.

To achieve the goal of increasing ecosystem service capacity for the mutual benefit of people and wildlife, wholesale change in livelihood activities may not be necessary. Rather, factoring in the linked needs of the 'blue-green corridor', and the benefits that may accrue from averting human-wildlife conflict as well as promoting traditional values relating to co-existence with wildlife, may enable communities to identify more considered and beneficial zonation of activities. This will not be achieved through a top-down, centrally mandated set of protocols. Such enforced measures are generally unenforceable, omit the local knowledge, insights and value systems of local people, are inconsistent with devolved decision-making about such natural resource development matters in rural India, and are therefore only likely to promote resentment and reactionary behaviours. Although this form of land conversion in a buffer zone at Amlidha may strictly be illegal, legal controls are only as effective as their enforcement and may also conflict with the legitimate aspirations of people to meet their needs. In developing world situations, alternative, often consensual community deliberation, market-based and other mechanisms may be more effective means for achieving sustainable natural resource management (Everard et al., 2009). India also has a devolved system of decision-making, with development decisions delegated to democratically elected village-scale Gram sabha (village councils). Around the villages in the Amlidha buffer zone, zonation of activities to accommodate human needs whilst providing effective 'green' and 'blue' wildlife pathways through the landscape is likely to be most effectively considered, accepted and enacted through Gram sabha, which not only provide a forum for debate and decision-making but also harness local knowledge about village needs and traditions as well as wildlife activity and routes. As integral part of villages and active herders, some tigerwalas play key roles in Gram sabha. It is therefore above all important that villagers are central to dialogue and identification of tenable solutions, rather than their needs being overlooked and so marginalised in imposed 'solutions'. These are, after all, the landscapes within which they live and of which they are stewards. They inhabit 'cultural landscapes' - landscapes produced as much by deliberate management by humans as by natural forces (Schaich et al., 2010) - the biodiversity and ecosystem services of which are shaped by complex, extended histories of settlement and land use (Antrop, 1997 and 2005; JonesWalters, 2008). Local people also possess a wealth of traditional knowledge, and may respond significantly to value systems - religious, folklore or other - that are not evident to technical 'experts', necessitating a community-based approach to solutions identification and agreement (Folke et al., 2005).

Community engagement and governance is instead essential for effective local decision-making and action to alleviate human-carnivore conflict, an approach found more generally to be central to large carnivore conservation requiring knowledge of underlying human and environmental drivers informing strategies better promoting co-existence (Thorn et al., 2012). In a South African study, conflict appears to have been driven more by social and environmental factors than by economic losses, which were found by survey not to have constituted a serious economic threat, so 
mitigation efforts that foster positive attitudes to carnivores may have greater impact than activities intended to reduce livestock predation losses (Thorn et al., 2012). In this regard, the Tiger Watch approach of working with local people, embedding education, awareness of predator and game movements and providing economic benefits for participants within local communities through the 'goatwala for tigertwala' and other initiatives makes a significant contribution to overcoming often unfounded fears as well as informing planning better to mitigate potential for conflict by integrating multiple perspectives and landscape functions into community land use decisions.

These types of community-based solutions are best promoted by local, trusted NGOs embedded within communities and understanding management objectives, such as wildlife and natural resource conservation, as well as local perspectives, priorities and protocols (Everard, 2015). Government institutions can play useful roles as enablers of more integrated local-decision-making. Government aspiration would be well-served by supporting integrated local decision-making and governance as synergistic outcomes across policy areas could be improved by collaboration between government departments to reconcile conflicting land uses, increasing transparency in developing land-use plans that reconcile extractive uses, illegal land clearance, hunting, poverty reduction and natural resource security, and the conservation of nature and associated ecosystem services in multiple-use landscapes (Chomitz et al., 2006; Gardner et al., 2007).

A sustainable approach making use of traditional and local knowledge is therefore to encourage community deliberation about optimal natural resource management for co-existence of 'green corridor', blue corridor' and livelihood needs. This may be promoted by the stimulus of introducing techniques such as participatory mapping as well as some education about the benefits of reducing the potential for wildlifehuman conflict and increasing water stress arising from recent land conversion, possibly best presented by the established network of 'Village wildlife volunteers' established by Tiger Watch. Ideally, this can lead to development of elective zonation, co-created consensually through existing village governance networks and structures. These bodies, informed where necessary about conservation goals and the benefits of co-existing with wildlife including reducing human-wildlife conflict, can then work towards agreements based on wise and beneficial stewardship of common pool resources, including respect for, protection and sympathetic uses of multifunctional habitat of the most critical importance as 'green' and 'blue' corridors. Additional management activities to protect or enhance ecosystem service capacities to avert conflict may be identified, such as dissuading further extension of ravine flattening, replanting or protecting corridors of suitable native vegetation and ravines to provide cover for migrating animals in critical zones, and management of trees that may deplete soil moisture and affect animal movement. Maintaining a matrix of habitat complexity also has the advantage of supporting prey species, reducing the likelihood of large predators hunting stock animals, whether deliberately or opportunistically. Further management activities may include collaboration to develop and maintain rainwater harvesting structures to regenerate and allow sharing of water resources from recharged wells and raised water tables, improving the quality of water available for domestic and stock use, alleviating pressure on wider water resources as well as avoiding hazards from wildlife encounters when fetching water from more distant sources that may necessitate crossing animal 
migration routes. Where local wells and groundwater have been regenerated elsewhere in Rajasthan, there has also been an observed significant reduction in drudgery amongst women and girls who have traditional roles gathering water, fodder and fuel wood, allowing them greater opportunity to engage in productive activities such as education, traditional medicine and village governance (Everard, 2015). Such societal co-benefits are significant factors in achieving engagement and support of local people, who are not only resource owners and stewards but critical to maintenance of cultural landscapes.

This builds upon an existing successful local track record of zonation and other behaviours promoting the co-existence of wildlife and people. Practical examples include the de facto, long-established diurnal zonation wherein stock animals graze the river corridor by day but are brought into protected corrals by night when large animals tend to migrate between core Reserve areas. Also the 'goatwala for tigertwala' and wider 'Village wildlife volunteers' programme has worked with villagers with interests both in stock management and nature conservation, embedding intelligence and advocacy for co-existence into the working landscape.

Achieving the longer-term goal of consensual zonation to protect or enhance ecosystem services capacity supporting simultaneous livelihood and nature conservation co-benefits will entail active advocacy and engagement, by necessity through a locally embedded NGO working with traditional local governance structures and using ecosystem services as a framework to explore benefits, vulnerabilities and win-win solutions. Outcomes for wildlife, people and the longterm resilience of the landscape and its many wildlife, livelihood, tourism, spiritual and other values will be of lasting significance. It will also potentially represent a transferrable model for the increasing number of situations globally where wildlifehuman conflict is likely to increase beyond the bounds of strictly managed core areas of designated reserves, or where human expansion impinges increasingly on previously undeveloped habitat.

\section{Acknowledgements}

Travel and subsistence for the senior author's field visits informing this study were supported by the RICS Research Trust (project number 490), for which we are sincerely grateful. The senior author is also grateful for co-funding by Lloyd's Register Foundation, a charitable foundation helping to protect life and property by supporting engineering-related education, public engagement and the application of research. Many thanks to Tiger Watch for local transport around the Ranthambhore and Amlidha area, and to Divya Khandal for feeding us whilst conducting research.

\section{References}

Abernethy, K.A., Coad, L., Taylor, G., Lee, M.E. and Maisels, F. (2013). Extent and ecological consequences of hunting in Central African rainforests in the twenty-first century. Philosophical Transactions of the Royal Society B, 368 (1625). 
Antrop, M. (1997). The concept of traditional landscapes as a base for landscape evaluation and planning: the example of Flanders Region. Landscape and Urban Planning, 38, pp.105-117.

Antrop, M. (2005). Why landscapes of the past are important for the future. Landscape and Urban Planning, 70(1-2), pp.21-34.

Bhagabati, N.K., Ricketts, T.H., Siswa Sulistyawan, T.B., Conte, M., Ennaanay, D., Hadian, O., McKenzie, E., Olwero, N., Rosenthal, A., Tallis, H. and Wolny, S. (2014). Biological Conservation, 169, pp.147-156.

Balme, G.A., Hunter, L.T.B. and Slotow, R. (2009). Evaluating methods for counting cryptic carnivores. Journal of Wildlife Management, 73(3), pp.433-441.

Bengali, S. (2016). 10 years ago India's tigers were vanishing. Here's how a few villagers with cameras are helping to save them. Los Angeles Times, $21^{\text {st }}$ June 2016. (http://www.latimes.com/world/asia/la-fg-india-tigers-snap-story.html, accessed $22^{\text {nd }}$ June 2016.)

Binggeli, P. (2001). The human dimensions of invasive woody plants. In: McNeely, J.A. (Ed.). The Great Reshuffling: Human Dimensions of Invasive Alien Species. IUCN, Gland, Switzerland and Cambridge, UK.

BioNET-EAFRINET. (Undated). Prosopis juliflora (Prosopis or Mesquite). BioNETEAFRINET.

(http://keys.lucidcentral.org/keys/v3/eafrinet/weeds/key/weeds/Media/Html/Prosopis juliflora (Prosopis or Mesquite).htm, accessed $30^{\text {th }}$ April 2016.)

Carbone, C., Pettorelli, N. and Stephens, P.A. (2011). The bigger they come, the harder they fall: body size and prey abundance influence predator-prey ratios. Biology Letters, 7(2), 312-315.

Caro, T. and O'Doherty, G. (1999). On the use of surrogate species in conservation biology. Conservation Biology, 13, pp.805-814.

Central Ground Water Board. (Undated). Ground Water Information: Tonk District, Rajasthan. Central Ground Water Board, Ministry Of Water Resources, Government Of India. (http://www.cgwb.gov.in/District Profile/Rajasthan/Tonk.pdf, accessed 30 ${ }^{\text {th }}$ April 2016.)

Central Water Commission. (Undated). National Register of Large Dams - 2009. (http://www.cwc.nic.in/main/downloads/National\%20Register\%20of\%20Large\%20Da ms\%202009.pdf, accessed 30th April 2016.)

Chape, S., Harrison, J., Spalding, M. and Lysenko, I. (2005). Measuring the extent and effectiveness of protected areas as an indicator for meeting global biodiversity targets. Philosophical Transactions of the Royal Society London B Biological Sciences, 360, pp.443-455. 
Chávez, C. and Ceballos, G. (2006). Memorias del Primer Simposio. El Jaguar Mexicano en el Siglo XXI: Situación Actual y Manejo. CONABIO-Alianza WWF Telcel-Universidad Nacional Autónoma de México. México D.F.

Chomitz, K.M., Buys, P., De Luca, G., Thomas, T.S. and Wertz-Kanounnikoff, S. (2006). At loggerheads? Agricultural expansion, poverty reduction, and environment in the tropical forests. pp.68-70. Washington, DC: World Bank.

CIA. (2015). The World Factbook - South Asia - India. Central Intelligence Agency. (https://www.cia.gov/library/publications/resources/the-world-factbook/geos/in.html, accessed $29^{\text {th }}$ April 2016.)

Davies, T., Everard, M. and Horswell, M. (2016). Community-based groundwater and ecosystem restoration in semi-arid north Rajasthan (3): evidence from remote sensing. Ecosystem Services, 21(A), pp.20-30.

Department of Environmental Affairs. (Undated). Working for Water (WfW) programme. Department of Environmental Affairs, Republic of South Africa. (https://www.environment.gov.za/projectsprogrammes/wfw, accessed $30^{\text {th }}$ April 2016.)

Department of Survey. (2007). The National Atlas of Sri Lanka ( $2^{\text {nd }}$ Edition). Department of Survey, p.86. ISBN 955-9059-04-1.

Department of Water Resources. (2000). Rivers - Banas Basin. Department of Water Resources, India. (http://waterresources.rajasthan.gov.in/3rivers2.htm, accessed $30^{\text {th }}$ April 2016.)

Díaz, S., Fargione, J., Chapin III, F.S. and Tilman, D. (2006). Biodiversity loss threatens human well-being. PLoS Biology, 4, 1300-1305.

Dinerstein, E., Loucks, C., Wikramanayake, E., Ginsberg, J., Sanderson, E., Seidensticker, J., Forrest, J., Bryja, G., Heydlauff, A., Klenzendorf, S., Leimgruber, P., Mills, J., O'Brien, T., Shrestha, M., Simons, R. and Songer, M. (2007). The fate of wild tigers. BioScience, 57, pp.508-514.

Eveleigh, M. (2016). Tiger Champions. BBC Wildlife Magazine, April 2016, pp.22-28.

Everard, M., Colvin, J.D., Mander, M., Dickens, C. and Chimbuya, S. (2009). Integrated catchment value systems. Journal of Water Resource and Protection (JWARP), 3, pp.174-187.

Everard, M. (2015). Community-based groundwater and ecosystem restoration in semi-arid north Rajasthan (1): socio-economic progress and lessons for groundwater-dependent areas. Ecosystem Services, 16, pp.125-135.

Everard, M. (2016). Community-based groundwater and ecosystem restoration in semi-arid north Rajasthan (2): reviving cultural meaning and value. Ecosystem Services, 18, pp.33-44. 
Farias, A.A. and Jaksic, F.M. (2011). Low functional richness and redundancy of a predator assemblage in native forest fragments of Chiloe Island, Chile. Journal of Animal Ecology, 80(4), pp.809-817.

Fishbase. (Undated a). Parambassis ranga (Hamilton, 1822): Indian glassy fish. Fishbase. (http://fishbase.org/summary/Parambassis-ranga.html, accessed $19^{\text {th }}$ May 2016.)

Fishbase. (Undated b). Eutropiichthys vacha (Hamilton, 1822): Batchwa vacha. (http://fishbase.org/summary/Eutropiichthys-vacha.html, accessed $19^{\text {th }}$ May 2016.)

Folke, C., Fabricius, C., Cundill, G., Schultz, L., Queiroz, C., Gokhale, Y., Marín, A., Camac-Ramirez, E., Chandola, S., Ahmed, M.T., Talukdar, B., Argumedo, A. and Torres, F.C. (2005). Chapter 11: Communities, Ecosystems, and Livelihoods. In: by Capistrano, D., Samper, C., Lee, M.J. and Raudsepp-Hearne, C. (Eds.) Ecosystems and Human Well-Being: Findings of the Sub-Global Assessments Working Group v.4: Multiscale Assessments (Millennium Ecosystem Assessment). Island Press, Washington D.C.

Forest Department. (1990). Ranthambhore Management Plan, 1991-1995. Forest Department, Government of Rajasthan, pp.9-11.

Forrest, J.L., Bomhard, B., Budiman, A., Coad, L., Cox, N., Dinerstein, E., Hammer, D., Huang, C., Huy, K., Kraft, R., Lysenko, I. and Magrath, W. (2011). Single-species conservation in a multiple-use landscape: current protection of the tiger range. Animal Conservation, 14(3), pp.283-294.

Gardner, T.A., Caro, T., Fitzherbert, E.B., Banda, T. and Lalbhai, P. (2007). Conservation value of multiple-use areas in East Africa. Conservation Biology, 21, pp.1516-1525.

Government of India. (2011). Indian census 2011. Government of India, Ministry of Home Affairs. (www.censusindia.gov.in, accessed $30^{\text {th }}$ April 2016.)

Hindustan Times. (2015). Flattening of Chambal ravines won't help. Hindustan Times, $19^{\text {th }}$ January 2015 . [online.]

(http://www.hindustantimes.com/comment/flattening-of-chambal-ravines-won-thelp/story-6kDT0PzfQoXkURJH8DmU8L.html, accessed $15^{\text {th }}$ January 2017.)

Jal Bhagirathi Foundation and Wells for India. (2010). Adapting water harvesting to climate change. Jal Bhagirathi Foundation (Jodhpur) and Wells for India (Udaipur).

Jhala, Y.V., Gopal, R. and Qureshi, Q. (Eds.) (2008). Status of the Tigers, Copredators, and Prey in India. TR 08/001. National Tiger Conservation Authority, Government of India, New Delhi; Wildlife Institute of India, Dehradun.

Jhala, Y.V., Qureshi. Q., Gopal. R. and Sinha, P.R. (Eds.). (2011). Status of Tigers, Co-predators and Prey in India, 2010. National Tiger Conservation Authority, Government of India, New Delhi, and Wildlife Institute of India, Dehradun. TR 2011/003 pp- 302. 
Jhala, Y.V., Qureshi, Q. and Gopal, R. (Eds.) (2015). The status of tigers in India 2014. National Tiger Conservation Authority, Government of India, New Delhi; Wildlife Institute of India, Dehradun.

(http://projecttiger.nic.in/WriteReadData/LetestNews/Document/Tiger\%20Status\%20 booklet XPS170115212.pdf, accessed $20^{\text {th }}$ June 2016.)

Jones-Walters, L. (2008). Biodiversity in multifunctional landscapes. Journal for Nature Conservation, 16, pp.117-119.

Kaur, K., Gonzáles, W.L., Llambi, L.D., Soriano, P.J., Callaway, R.M., Rout, M.E., Gallaher, T.J. and Inderjit. (2012). Community Impacts of Prosopis juliflora invasion: biogeographic and congeneric comparisons. PlosONE, http://dx.doi.org/10.1371/journal.pone.0044966, accessed $28^{\text {th }}$ January 2017.

Khandal, D. and Khandal, D. (2013). Ravines ecology: Waste to wealth. Saevus Wildlife India Magazine, September-October, pp.72-77.

Kier, G., Mutke, J., Dinerstein, E., Ricketts, T.H., Küper, W., Kreft, H. and Barthlott, W. (2005). Global patterns of plant diversity and floristic knowledge. Journal of Biogeography, 32, pp.1107-1116.

Lambeck, R.J. (1997). Focal species: a multi-species umbrella for nature conservation. Conservation Biology, 11, pp.849-856.

Lawton, J. (2010). Making Space for Nature: A Review of England's Wildlife Sites and Ecological Network. Department for Environment, Food and Rural Affairs, London. (www.defra.gov.uk/environment/biodiversity/documents/201009space-fornature.pdf, accessed $29^{\text {th }}$ April 2016.)

Linkie, M., Martyr, D.J., Holden, J., Yanuar, A., Hartana, A.T., Sugardjito, J. \& Leader-Williams, N. (2003). Habitat destruction and poaching threaten the Sumatran tiger in Kerinci Seblat National Park, Sumatra. Oryx, 37, pp.41-48.

Mace, G.M., Norris, K. and Fitter, A.H. (2012). Biodiversity and ecosystem services: a multilayered relationship. Trends in Ecology and Evolution, 27, pp.19-26.

Mahnot, S.C., Singh, P.K. and Chaplot, P.C. (2012). Chapter 21: Water erosion control measures on non-arable lands. In: Soil and water conservation and watershed management. Apex Publishing House, Udaipur-Jaipur.pp.205-238.

Merchant, C. (2007). American Environmental History: An Introduction. Columbia University Press.

Millennium Ecosystem Assessment. (2005a). Ecosystems and Human Well-being: Synthesis. Washington DC: Island Press.

Millennium Ecosystem Assessment. (2005b). Ecosystems and Human Well-being: Wetlands and Water Synthesis. World Resources Institute, Washington, DC. 
NTCA. (2014). Status of tigers In India, 2014.

Naidoo, R., Balmford, A., Costanza, R., Fisher, B., Green, R.E., Lehner, B., Malcolm, T.R. and Ricketts, T.H. (2008). Global mapping of ecosystem services and conservation priorities. Proceedings of the National Academy of Sciences, 105, pp.9495-9500.

O'Brien, T.G., Kinnaird, M.F. and Wibisono, H.T. (2003). Crouching tigers, hidden prey: Sumatran tiger and prey populations in a tropical forest landscape. Animal Conservation, 6, pp.131-139.

Panwar, H.S. (1987). Project Tiger: The reserves, the tigers, and their future. In: Tilson, R. L., Sel, U. S., Minnesota Zoological Garden, IUCN/SSC Captive Breeding Group, IUCN/SSC Cat Specialist Group. Tigers of the world: the biology, biopolitics, management, and conservation of an endangered species. Noyes Publications, Park Ridge, N.J., pp. 110-117.

Pasiecznik, N., Felker, P., Harris, P.J.C., Harsh, L.N., Cruz, G., Tewari, J.C., Cadoret, K. and Maldonado, L.J. (2001). The Prosopis juliflora-Prosopis pallida complex: A monograph. HDRA, Coventry, UK.

Prugh, L.R., Stoner, C.J., Epps, C.L., Bean, W.T., Ripple, W.J., Laliberte, A.S. and Brashares, J.S. (2009). The Rise of the Mesopredator. BioScience, 59(9), pp.779791.

Ramsar Convention Secretariat. (2010). Wise use of wetlands: Concepts and approaches for the wise use of wetlands. Ramsar handbooks for the wise use of wetlands, 4th edition, vol. 1. Ramsar Convention Secretariat, Gland, Switzerland. (http://www.ramsar.org/sites/default/files/documents/library/hbk4-01.pdf, accessed $30^{\text {th }}$ April 2016.)

Riegelhaupt, E., da Silva, I.B., Campello, F.B. and Pareyn, F. (2008). Volume, Weight and Product Tables for Prosopis juliflora (Sw) dc at Rio Grande do Norte. UN Food and Agriculture Organisation.

(http://www.fao.org/docrep/006/ad317e/ad317e03.htm, accessed 30 ${ }^{\text {th }}$ April 2016.)

Rosas-Rosas, O.C. and Valdez, R. (2010). The role of landowners in jaguar conservation in Sonora, Mexico. Conservation Biology, 24(2), pp.366-371.

Sanderson, E., Redford, K.H., Vedder, A., Coppolillo, P. and Ward, S. (2001). A conceptual model for conservation planning based on landscape species requirements. Landscape and Urban Planning, 58, pp.41-56.

Schaich, H., Bieling, C. and Plieninger, T. (2010). Linking Ecosystem Services with Cultural Landscape Research. GAIA, 19(4), pp.269 - 277.

Schipper, J., Chanson, J.S., Chiozza, F., Cox, N.A., Hoffmann, M., Kataryia, V., Lamoreux, J., Rodrigues, A.S.L., Stuart, S.N., Temple, H.J., Baillie, J., Boitani, L., Lacher Jr., T.E., Mittermeier, R.A., Smith, A.T. and Williamson, E.A. (2008). The 
status of the world's land and marine mammals: diversity, threat and knowledge. Science, 322(5899), pp.225-230.

Silva, J.P., Toland, J., Hudson, T., Jones, W., Eldridge, J., Thorpe, E., Bacchereti, S., Nottingham, S., Thévignot, C. and Demeter, A. (2013). LIFE and human coexistence with large carnivores. European Union.

(http://ec.europa.eu/environment/nature/conservation/species/carnivores/pdf/life and human coexistence with large carnivores.pdf, accessed $28^{\text {th }}$ April 2016.)

Singh, R., Krausman, P.R., Goyal, S.P. and Chauhan, N.S. (2015a). Factors contributing to tiger losses in Ranthambhore Tiger Reserve, India. Wildlife Society Bulletin, 39(3), pp.670-673.

Singh, R., Nigam, P., Qureshi, Q., Krausman, P.R., Goyal, S.P. and Nicholoson, K.L (2015b). Characterizing human-tiger conflict in and around Ranthambhore Tiger Reserve, western India. European Journal of Wildlife Research, 61(2), pp.255-261.

Srinivasan, V., Gorelick, S.M. and Goulder, L. (2009). Sustainable urban water supply in south India: Desalination, efficiency improvement, or rainwater harvesting? Water Resources Research, 46, W10504. doi:10.1029/2009WR008698.

Tewari, J.C., Harris, P.J.C, Harsh, L.N., Cadoret, K. and Pasiecznik, N.M. (2000). Managing Prosopis juliflora (Vilayati babul): A Technical Manual. CAZRI, Jodhpur, India and HDRA, Coventry, UK. 96pp.

Thorat, O.H. and Gurjer, R. (2010). Identification and quantification of anthropogenic pressure on corridor between Ranthambhore National Park and Kailadevi Wildlife Sanctuary. Tiger Watch: A report submitted to Forest Department. Tiger Watch, Sherpur Khiljipur, Rajasthan (http://www.tigerwatch.net/docs/kailadevi wls.pdf, accessed $20^{\text {th }}$ June 2016.)

Thorn, M., Green, M., Dalerum, F., Bateman, P.W. and Scott, D.M. (2012). What drives human-carnivore conflict in the North West Province of South Africa? Biological Conservation, 150(1), pp.23-32.

Times of India. (2013). Illegal mining rampant in Banas, Chambal rivers. The Times of India, $7^{\text {th }}$ August 23013. (http://timesofindia.indiatimes.com/city/jaipur/lllegalmining-rampant-in-Banas-Chambal-rivers/articleshow/21663897.cms, accessed $2^{\text {nd }}$ January 2017.)

Treves, A. and Karanth, K.U. (2003). Human-carnivore conflict: Local solutions with global applications. Conservation Biology, 17, pp.1489-1490.

Turner, W.R., Brandon, K., Brooks, T.M., Costanza, R., Da Fonseca, G.A.B. and Portela, R. (2007). Global Conservation of Biodiversity and Ecosystem Services. BioScience, 57, pp.868-873.

Upadhyay, A. and Rai, R.K. (2013). Case Study: Banas Catchment. In: Upadhyay, A. and Rai, R.K. (eds.) Water Management and Public Participation. Springer Briefs in Earth Sciences, DOI: 10.1007/978-94-007-5709-7_7. 
Verma, M., Negandhi, D., Khanna, C., Edgaonkar, A., David, A., Kadekodi, G., Costanza, R. and Singh, R. (2015). Economic Valuation of Tiger Reserves in India: A Value+ Approach. Indian Institute of Forest Management. Bhopal, India.

Wells for India. (2016). Before and after. WaterWise, 62 (Autumn 2016), p.10.

Wilson, E.O. (1990). Biophilia: The Human Bond with Other Species. Harvard University Press. 